\title{
НОСТАЛЬГИЧЕСКИЕ МОТИВЫ В СОНЕТЕ АДАМА МИЦКЕВИЧА АККЕРМАНСКИЕ СТЕПИ И ИХ ОТРАЖЕНИЕ В РУССКИХ ПЕРЕВОДАХ
}

\author{
NOSTALGIC MOTIVES IN ADAM MICKIEWICZ'S SONNET \\ THE ACKERMAN STEPPE AND THEIR REFLECTION \\ IN RUSSIAN TRANSLATIONS
}

\author{
МАРИЯ КОЗЫРЕВА
}

\begin{abstract}
Aвstract. The paper deals with the nostalgic motives in Adam Mickiewicz's sonnet The Ackerman Steppe, expressed in the imagery of the poem, and their reflection in Russian translations, which were published in different periods from the 19th century up to our times. The author examined how the epoch and the translator's position influenced the perception of the images.
\end{abstract}

Keywords: Mickiewicz, sonnet, Crimean sonnets, nostalgia, imagery, translation, interpretation

Мария Козырева, Казанский федеральный университет, Казань - Россия, kozyr2m@mail.ru ORCID ID: 0000-0003-2015-1183

Адам Мицкевич является, пожалуй, одним из самых известных в России польских авторов. Его творчество в целом, а также его восприятие в России, в том числе и через перевод, достаточно исследованы. Так, среди работ последних десятилетий, посвященных переводам Крымских сонетов, следует отметить статьи Олега Федотова [Федотов 1998], Людмилы Рогожевой-Карпович [Рогожева-Карпович 2013], Ирины Великодной [Великодная 2003], Людмилы Порубай [Порубай 2015] и ряд других. Процесс активного переводческого освоения поэзии Мицкевича начался еще при его жизни, с тех пор не прерывался и продолжается по настоящий день. Особой популярностью среди русских переводчиков и читателей всегда пользовались его Крымские сонеты. Среди произведений этого цикла особо выделяется сонет Аккерманские степи. Нами было обнаружено двадцать пять опубликованных переводов, не считая любительских, при этом возможно, это далеко не полный список. Уже в 1828 году, то есть всего лишь через пару лет после появления сонета, существовало уже четыре интерпретации: Петра Вяземского (подстрочный перевод), Алексея Илличевского, Ивана Козлова, Юрия Познанского. 
Мы уже рассматривали в свое время отдельные аспекты переводов этого произведения [Козырева 1999]. В данной статье мы остановимся прежде всего на том, как отражают переводчики основную тему сонета - тоску по родине. Материалом для нас будут служить как уже исследованные нами переводы, так и те, которые не затрагивались ранее. Это переводы Афанасия Фета 1854 года [Фет 1912: 304], Ивана Куклина 1892 года [Мицкевич 1998], Владимира Коробова 1997 года [Мицкевич 1998], Людмилы Рогожевой 2013 года [Рогожева 2013], а также ставший хрестоматийным в русской культуре перевод Вильгельма Вениаминовича Левика 1955 года [Мицкевич 1976: 76]. Теоретической основой нашего исследования являются труды Андрея Федорова [Федоров 1983; Федоров 2002], Ефима Эткинда [Эткинд 1963], касающиеся вопросов и особенностей поэтического перевода, а также работы по истории польско-русских литературных взаимодействий [см. Цыбенко 1978; Ивинский 2003].

Сонет Аккерманские степи был написан в 1825 году, в одесский период ссылки, когда Мицкевич со своим знакомым поляком, местным помещиком Каролем Мархоцким, отправился в Аккерман, чтобы встретиться с другом, Серафимом Гациским, сосланным туда. В имении Махроцкого и был создан сонет. В это время Мицкевич еще не помышляет о будущем цикле, строго говоря, первый сонет и не посвящен Крыму, однако в нем с удивительной силой звучит ностальгический мотив, который является связующей нитью всего цикла. Ориентализм, присущий другим крымским сонетам, здесь выражен слабо.

В начале сонета, в первом катрене, все подчинено мягкому движению покачивающегося возка, уподобляемого движенью лодки по воде.

Wpłynąłem na suchego przestwór oceanu,

Wóz nurza się w zieloność i jak łódka brodzi,

Śród fali łąk szumiących, śród kwiatów powodzi,

Omijam koralowe ostrowy burzanu.

[Mickiewicz 1928]

Однако океан для Мицкевича - это не только бескрайний простор, романтический символ свободы, но и море житейское в христианском понимании, страсти и испытания, ждущие пловца. Надвигающаяся тьма во втором катрене вызывает у путника нарастающее чувство тревоги, а внезапный и загадочный блеск маяка провоцирует желание остановиться. Это переломная точка.

Już mrok zapada, nigdzie drogi ni kurhanu;

Patrzę w niebo, gwiazd szukam, przewodniczek łodzi;

Tam z dala błyszczy obłok - tam jutrzenka wschodzi?

To błyszczy Dniestr, to weszła lampa Akermanu.

[Mickiewicz 1928] 
Если первые четыре строки - это просто пейзажная зарисовка, последующие две - уже личностная оценка увиденного, тревога, то в третьей - появившийся в дали свет вызывает радость: „Tam zdala błyszczy obłok? tam jutrzenka wschodzi? To błyszczy Dniestr, to weszła lampa Akermanu!" Отблеск на облаке, утренняя звезда, блеск реки и зажегшийся маяк - все это путеводный свет. Надежда вызывает желание остановиться.

Первый терцет открывает вторую часть сонета, непосредственно выражающую ностальгическую тему:

Stójmy! - jak cicho! - słyszę ciągnące żurawie,

Których by nie dościgły źrenice sokoła;

Słyszę, kędy się motyl kołysa na trawie,

Kędy wąż śliską piersią dotyka się zioła.

W takiej ciszy - tak ucho natężam ciekawie,

Że słyszałbym głos z Litwy. - Jedźmy, nikt nie woła.

[Mickiewicz 1928]

Возникшая тишина позволяет путнику услышать далекий полет журавлей, трепет крыльев мотылька, шуршание ужа в траве и - ожидание услышать зов с родины, Литвы. Но никто не зовет, и лирический герой призывает продолжить путь. На контрасте строгого, почти документального описания степи у Аккермана и пронзительной тоски по родине, выплескивающейся в заключительной строке, и строится драматический конфликт сонета. Однако надежда услышать голос с родины вызвано именно тем, что слышит герой в вечерней тиши. Это курлыканье журавлей, напоминающее о доме (кстати, в значении „вольность” и „голос с родины" образ этот встречается и у самого Мицкевича в русской части Дзядов, и у других польских поэтов-изгнанников Юлиуша Словацкого и Циприана Норвида). Следующий сразу после этого образ соколов как гордых и зорких птиц, свободных и смелых, - это тоже воспоминание о родине, а тихий уж - образ, встречающийся во многих литовских сказках и легендах. Так, существа южной степи связывают лирического героя-изгнанника с далеким родным краем.

В целом отдельные образы сонета просты, их сочетание, переплетение и более широкий культурный контекст формируют романтический пафос и двоемирие. Так, ладья, плывущая на маяк в гавань, в символике ранних христиан означает путь души к вечной жизни. У Мицкевича, соответственно, это путь к идеальному, другому миру, но для него, изгнанника, этот мир - на родине, в Литве, вполне реальной.

Переводы с родственных языков, особенно, когда переводческое искусство в воспринимающей культуре находится на высоком уровне, имеют свои особенности. Не сталкиваясь с особыми сложностями при 
восприятии основной идеи, размера, лексических особенностей, переводчик имеет, казалось бы, большую свободу, и поэтому процесс перевода упрощается. С другой стороны, именно языковая близость, совпадение многих слов и их значений ставят переводчика в жесткие рамки, делая во многих случаях неоправданным прием функциональных замен, расставляя при этом многочисленные языковые ловушки. Поэтому сначала рассмотрим, как переводчики передают основные образы сонета, формирующие ностальгический мотив.

Первая строка сонета „Wpłynąłem na suchego przestwór oceanu” не вызвала сложностей и в большинстве случаев передана фактически дословно.

Фет: „Всплываю на простор сухого океана”,

Куклин: „Я выплыл на простор сухого океана",

Левик: „Я выплыл на простор сухого океана”,

Рогожева: „Плыву просторами сухого океана”,

Коробов: „Вплываем на волнах степного океана в просторы диких трав”.

В оригинале образ океана усилен еще и последующей метафорой: „koralowe ostrowy burzanu”. Заросли бурьяна, возвышающиеся то здесь, то там, ассоциируются у поэта с коралловыми рифами. Таким образом, с одной стороны, он подчеркивает опасность плаванья по житейскому морю, с другой - придает красочность пейзажу, с третьей - придает пейзажу экзотичность, усиливает осознание отдаленности от родного края. В переводах эта специфика образа в большинстве случаев сохранена.

Фет: „Минуя острова кораллов из бурьяна”,

Куклин: „Плыву меж островов коралловых бурьяна”,

Левик: „...меж островов коралловых бурьяна”.

Рогожева усиливает метафору: „Как риф, коралловые заросли бурьяна", а вот Коробов делает бурьян багряным, как, например, его предшественник Иван Бунин: „Минуя острова багряные бурьяна” [Мицкевич 1976: 212].

Момент явления „lampy Akermanu” у большинства переводчиков (исключение составляют переводы Левика и Куклина) сохраняет вопросительную интонацию подлинника. Этот же прием встречается и у других переводчиков: Майкова, Советова, Румера.

Фет: „Вдали там облако, зарницу ль вижу я? То светит Днестр, взошла лампада Аккермана",

Рогожева: „Что это? Облако в сиянии зари? - там серебрится Днестр - маяк у Аккермана", 
Коробов: „Что там горит? Заря? Зарницы ли цветок? Мерцает млечно Днестр, маяк у Аккермана",

Куклин: „Денница всходит - блещет облако в дали... То Днестр блестит, зажглась лампада Аккермана".

У Левика так же: „Алеют облака - заря глядит в разрыв; Зажегся на Днестре маяк у Аккермана". Замена вопросительной интонации утверждением нивелирует скрытые в этой строчке внутренние сомнения лирического героя, его тревогу и волнение, переходящее затем в осознание реальности.

Заметим попутно, что почему-то абсолютное большинство переводчиков, известных нам, избегают образа утренней звезды, а говорят о заре, рассвете, зарнице, таким образом, снимая смысловой пласт „путеводная звезда”.

Образ тянущегося клина журавлей в основном сохраняется в значении оригинала.

Куклин: „Чу...слышу журавлей полет”,

Левик: „Курлычут журавли в померкшей вышине”,

Коробов: „,...скрытые от глаз курлычут журавли",

Рогожева: „К Клин журавлей вершит таинственный полет”.

Однако перевод Фета грешит здесь ужасающей безвкусицей: „Я слышу стадо мчится: То журавли".

Соколы же исчезают из болышинства переводов. Обычно переводчиками используются функциональные замены для передачи этих строк. У Рогожиной журавли „летят незримо”, а у Коробова они „скрыты от глаз". Определенную сложность вызывает уж, необходимый Мицкевичу здесь как образ, напоминающий ассоциативно о Литве. На русский слово „wąż” может быть переведен и как уж, и как змея, змейка. Во многих более ранних переводах, в частности, в первом подстрочном переводе Вяземского, используется это значение, и возникает мотив коварства, опасности:

Вяземский: „Как змея дотрагивается до растений скользкой грудью” [Мицкевич 1976: 104],

Майков: „...как змей по злаку грудью скользкою ползет” [Мицкевич 1976: 150], Коринфский: „Как шелестит змея песком в овражном дне” [Мицкевич 1976: 206], Любич-Романович: „Там змей, скользящей грудью касаясь, злаки гложет” [Мицкевич 1976: 130].

Из анализируемых здесь переводов:

Рогожева: „...змея в траве ползет”.

Фет: „И грудью скользкой уж по зелени ползет”,

Куклин: „Как скользкий уж ползет между стеблями”,

Левик: „Как скользнул и притаился уж”,

Коробов: „Как выползает уж из логова ночного”. 
Таким образом, в большинстве анализируемых переводов система образов, ассоциативно связанных с Литвой, в целом, сохранена. Однако трагическое звучание последних строк: „W takiej ciszy tak ucho natężam ciekawie, Że słyszałbym głos z Litwy... Jedźmy, nikt nie woła!" - не отражается в полной мере. Если у Мицкевича осознание того, что голос из Литвы не прозвучит, сколь бы он ни прислушивался, подталкивает лирического героя к движению вперед по волнам сухого океана, по-видимому, к маяку в гавани, то есть в бесконечность, большинство переводчиков убирает призыв к движению: „Jedźmy”.

Фет: „Такая тишь, что мог бы в слухе отразиться и зов с Литвы... Но нет, никто не позовет",

Куклин: „В такой тиши так жадно напрягал я слух, Что внял бы зов с Литвы, но тихо все вокруг",

Рогожева: „Какая тишина! И кажется: родимый С Литвы услышу зов... Никто нас не зовет!",

Коробов: „...так сон глубок травы, Что, кажется, смогу почуять зов с Литвы... Молчание. Ни отзвука. Ни слова".

Горькая мысль „nikt nie woła” становится, таким образом, не толчком к движению, а точкой. В то же время у Левика: „Так слух мой напряжен, что в этой тишине Уловит зов с Литвы!.. но в путь! Не слышно зова".

Итак, рассмотрев в ряде русских переводов сонета Мицкевича Аккерманские степи пути передачи ключевых образов, а также интонационного рисунка, формирующие основной романтический конфликт сонета „здесь и там”, „в изгнании - далекая родина”, можно прийти к выводу, что большинство переводчиков справилось с этой нелегкой задачей. Хотя перевод Фета грешит некоторой неуклюжестью (кроме приведенного примера можно еще указать на „мотылек на травке шевелится"), а у Коробова встречаются неуклюжие обороты („смогу почуять зов с Литвы"), в целом все они могут быть определены как адекватные, поскольку воссоздают и форму, и содержание оригинала. Но поскольку цель адекватного перевода - вызвать у читателя своей культуры те же мысли и ассоциации, которые вызывал оригинал у своего читателя, а ассоциативные ряды, представленные нами раньше, могут возникнуть не у каждого русского читателя, современные переводчики находят другие пути, чтобы усилить ощущение боли от тоски по родине лирического героя. Так, у Рогожевой „Родимый с Литвы услышу зов”, у Коробова последние слова падают, как камни: „Молчание. Ни отзвука. Ни слова”. Самым удачным представляется перевод Левика, который точно передает не только образную систему и интонацию сонета, но и его мелодику. Избегая переводческих экспериментов и функциональных замен, он допускает отход от оригинала, активно используя аллитерацию: звук «л» 
пронизывает весь текст сонета, с одной стороны, подчеркивая движение, а с другой - связывая все происходящее с образом Литвы и создавая ностальгическую атмосферу не только непосредственно через образную систему, но и суггестивно.

Огромное количество переводов этого поэтического текста на русский язык свидетельствует о необходимости еще более точной передачи оттенков оригинала. Вспомним эпиграф к сонету и ко всему циклу из Гете: „Wer den Dichter will verstechen, Muss in Dichter's Lande gehen” („Кто хочет поэта постичь, должен отправиться в страну поэта”) [Мицкевич 1948: 234].

\section{Библиография}

Адельгейм И. 1998. А. Мицкевич. Разговор. Сомнение. Аккерманские степи, „Иностранная литература", №11, электронный ресурс: http://magazines.russ.ru/inostran/1998/11/mick.htm 1 (доступ 25.08.2017).

Великодная И. 2003. Петр Андреевич Вяземский - переводчик „Крымских сонетов" Адама МицкеВича, электронный ресурс: http://sites.utoronto.ca/tsq/10/velikodnaya10. shtml (доступ 25.08.2017).

Ивинский Д. И. 2003. Пушкин и Мицкевич: история литературных отношений, Москва: Языки славянской культуры.

Козырева М. 1999. Сонет Адама Мицкевича "Акерманские степи" в русских переводах, [в:] R. Fieguth (ред.) Adam Mickiewicz. Kontext und Wirkung. Contexte et rayonnement. Materialien der Mickiewicz -Konferenz in Frieburg/Schweiz, Frieburg: Universitatverlag Freiburg Schweiz.

Магомедзагиров Р. Т. 2016. Методы и принципы поэтического перевода. Переводческие преобразования при переводе поэзии? „Вестник РУДН. Русский и иностранный языки и методы их преподавания", № 4.

Малыгин В. Т. 2017. О возможностях перевода поэтического дискурса, „Мир лингвистики и коммуникации: электронный научный журнал", № 4, электронный ресурс: www.tverlingua.ru (доступ 20.04.2018).

Мицкевич А. 1948. Собрание сочинений 85 томах, т. 1, Москва: ОГИЗ.

Мицкевич А. 1976. Сонеты, Ленинград: Наука.

Мицкевич А. 1998. Аккерманские степи, „Иностранная литература”, № 11, электронный ресурс: http://magazines.russ.ru/inostran/1998/11/akker.html (доступ 10.09.2017).

Порубай Л. Н. 2015. Крымские сонеты, „Крымский архив”, № 3 (18).

Рогожева-Карпович Л. 2013. Крымские сонеты в творчестве Адама Мицкевича, электронный ресурс: http:/ / www.proza.ru/2013/01/10/2144 (доступ 10.09.2017).

Федоров А. В. 1983. Искусство перевода и жизнь литературы, Ленинград: Советский писатель.

Федоров А. В. 2002. Основы общеей теории перевода (Лингвистические проблемы), Москва: Филология. 
Федотов О. И. 1998. Встреча у Чатырдага, или толерантность художественного перевода (три варианта сонета Мицкевича "Widok gór ze stepów Kozłowa” на русском языке), „Prace Naukowe Wyższej Szkoły Pedagogicznej w Częstochowie”, № 7.

Фет А. А. 1912. Полное собрание сочинений - Приложение к журналу „Нива” на 1912 2, т. 2, Санкт-Петербург: Тов-во А.Ф. Маркс.

Цыбенко Е. 3. 1978. Из истории польско-русских литературных взаимодействий XIX-XX веков, Москва: МГУ.

Эткинд Е. Г. 1963. Поэзия и перевод, Москва-Ленинград: Советский писатель.

Mickiewicz A. 1928. Poezje, т. 2, Kraków: Krakowska Spółdzielnia Wydawnicza, электронный ресурс: https://wolnelektury.pl/media/book/pdf/sonety-krymskie-stepy-akermanskie.pdf (доступ 25.09.2017).

Straszewska M. 1977. Romantyzm, Warszawa: Wydawnictwo Szkolne i Pedagogiczne. 